$\underline{\text { Review Article }}$

\title{
PHARMACOGNOSTIC, ETHNOPHARMACOLOGICAL, PHYTOCHEMICAL AND PHARMACOLOGICAL PROFILE OF WILD GUAVA I.E. CAREYA ARBOREA ROXB
}

\author{
MANBIR KAUR ${ }^{*}{ }^{1}, 2$, RAKESH YADAV 1 \\ ${ }^{1}$ Department of Pharmaceutical Sciences, Banasthali Vidyapeeth, Banasthali, Rajasthan, ${ }^{2}$ Khalsa college of Pharmacy, G. T. Road, Amritsar, \\ Punjab, India \\ Email: manbirmanu@yahoo.com \\ Received: 27 Dec 2016, Revised and Accepted: 20 Mar 2017
}

\section{ABSTRACT}

Careyaarborea Roxb. is a medium-sized deciduous tree of 9 to $18 \mathrm{~m}$ height, surviving throughout India up to an altitude of 1,500 meters and other Asian countries. The tree belongs to

Family Lecythidaceae and has folklore use in treating cold, cough, tumours, asthma, inflammations, ulcers and skin infections. The present review reveals updated, comprehensive and categorized information on pharmacognostical evaluation containing morphology as well as microscopic studies, ethnopharmacology, physiochemical parameters, preliminary photochemical screening, phytochemistry and elaborated pharmacological studies.

Keywords: Careyaarborea, Slow match tree, Lecythidaceae, Microscopy, Biological activity

(C) 2017 The Authors. Published by Innovare Academic Sciences Pvt Ltd. This is an open access article under the CC BY license (http://creativecommons.org/licenses/by/4.0/) DOI: http://dx.doi.org/10.22159/ijcpr.2017v9i3.18887

\section{INTRODUCTION}

Nature has been a source of therapeutic agents for thousands of years and a tremendous number of novel drugs have been discovered from natural sources. India is known as "Botanical Garden of the world" as it has a huge diversity of medicinal plants. Moreover, Medicinal plants have played important role in the development of material medica.

In 1819 a genus of flowering plants in the family Lecythidaceae was described as Careya [1]. Lecythidaceae is included in the order Ericales, is considered monophyletic [2]. The word Lecythidaceae means large woody trees bearing large fruits with woody skins. The family comprises of tropical trees consisting of about 20 genera and 450 species $[2,3]$.

The genus careya includes three different species which includes Careyasphaerica Roxb, Careyaherbacea Roxb and Careyaarborea Roxb. Careyaarborea is a deciduous tree about $20 \mathrm{~m}$ high and is known as 'Padmaka' in Ayurveda [4]. The accepted botanical name is kumbi [5] and "Wild guava" in English [6]

The leaves are simple, broadly obovate in shape, acuminate apex with crenate, dentate margin, petioles $(0.1-1.8 \mathrm{~cm})$ long. Flower yellowish white, ill-smelling, sessile; fruits large, round, green and fleshy; seed embedded in the fleshy pulp of the fruit. Bark dark grey exfoliating in thin strips.

Taxonomic hierarchy

Kingdom: Plantae

Division: Angiosperms

Class: Eudicots

Subclass: Asterids

Order: Ericales

Family: Lecythidaceae

Genus: Careya

Species: Arborea
Synonyms [7]

Sanskrit: Svadupuapa, Vitapi, Sthalakumbhi, Romasa

Bengali: Kumbhi

Hindi: Sthalakumbhi

Kannada: Daddala, Gudda, Daddippe

Malayalam: Pezuntol

Marathi: Kumbhaa

Tamil: Kumbi

Telugu: Dudippi

English name: Slow match tree

Morphological features of Careyaarborea

1. Medium sized deciduous tree with height about $20 \mathrm{~m}$.

2. The surface of bark is fissured and dark grey in colour.

3. Leaves are simple, broadly obovate, tapering towards base, stipulated and the margin is crenate, shortly petiolated, glabrous.

4. The inflorescence is terminal and raceme.

5. Flowers bisexual, yellowish green with red-purple stamens; calyx and petals are free and 4-4 in number, inferior ovary, multilocular with many ovules arranged in 2 rows, style 1.

6. Fruit is drupe, many-seeded, globose to depressed globose, crowned by sepals. Fruit skin is leathery, pulp fleshy, not splitting.

7. Seeds exalbuminous, dark brown in colour, oval, ellipsoid, 1.5 to 2 $\mathrm{cm}$ long, indehiscent; testa hard and wrinkled.

\section{Leaf microscopy [8]}

8. Transverse section of the leaf through midrib region shows slight upper epidermis and large epidermis at the lower surface (fig. 2). Epidermal cells are thin walled and rectangular in shape, covered with thick cuticle followed by collenchymatous ground tissue. 


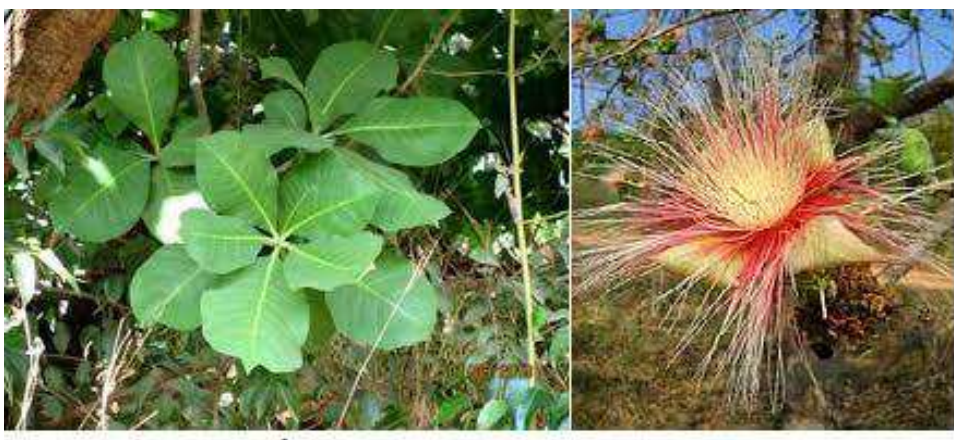

A

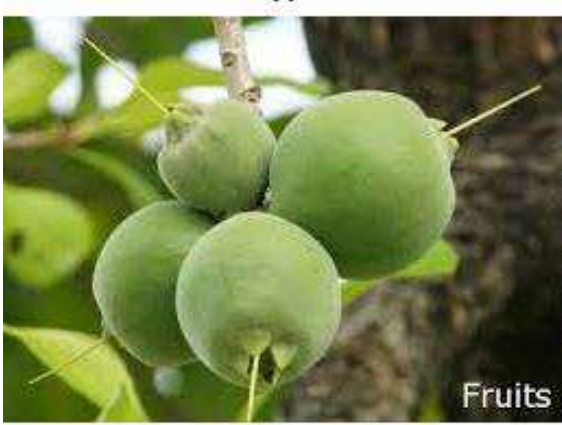

C
B

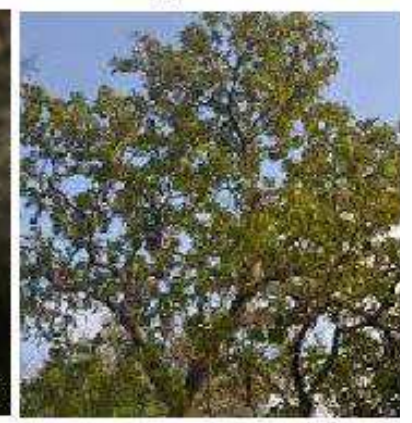

D

Fig. 1: A. Leaves of Careyaarborea, B. Flower of Careyaarborea, C. Fruits of Careya arborea, D. Careyaarboreatree

Palisade cell is single layered; midrib region shows one median large size vascular bundle and two lateral vascular bundles. Sclerenchyma is present at the upper notched side above the median vascular bundle. Xylem is arranged in cup-shaped and surrounded by phloem facing toward the lower side. Xylem consists of vessels, tracheids, fibres and xylem parenchyma. The lateral vascular bundle also shows sclerenchymatous bundle sheath which encircles the vascular bundle. Sclerenchymatous bundle sheath is broad on both surfaces and only 1 or 2 layered on the lateral side. TS passing through lamina region showed single layered palisade cells followed by several layers of spongy mesophyll embedded with lateral vascular bundles. C. arborea leaf surface shows the anisocytic stomata which is characteristic of Family Lecthyidaceae.

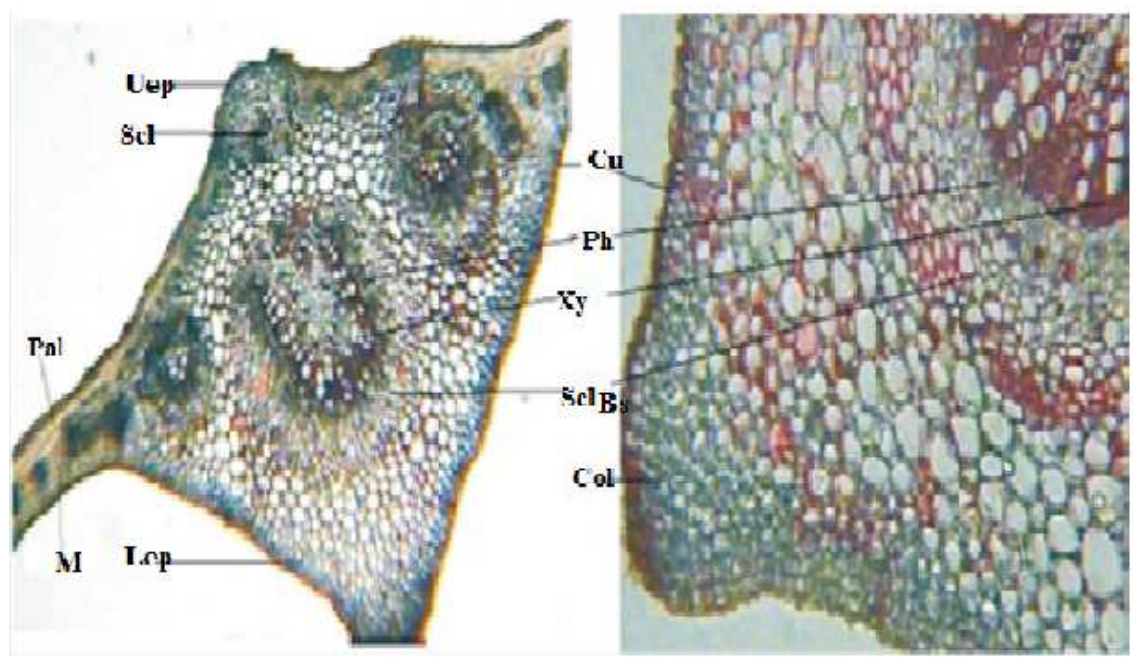

Fig. 2: T. S. of $C$. arboreal leaf. Uep upper epidermis, Lep lower epidermis, Cu cuticle, Pal, Palisade, Scl: sclerenchyma, Col: collenchymas, M: messophyll, X: xylem, P: Phloem, SclBS; Sclerenchyma Bundle sheath

\section{Stem microscopy [8]}

The stem of careyaarborea under a microscope shows outer cork $(3$ to 4 layered); cork cambium (1 to 2 layered) followed by collencymatous cortex with embedded vascular bundles (fig. 3). Cortical vascular bundles of various shape and size are present and surrounded by sclerenchymatous bundle sheath. Pericycle is present. Phloem, consisting of phloem fibers, sieve tubes, companion cells and phloem parenchyma followed by vascular cambium 4 to 5 layered and 4 to 5 cells broad in continuous layers. Xylem consists of vessels, tracheids, fibres and xylem parenchyma; medullary rays 1 to 2 cells broad and radiating; vessels are mostly solitary towards the centre and in a group of 2 to 4 towards the periphery. The Central portion is occupied by collenchymatous pith. 


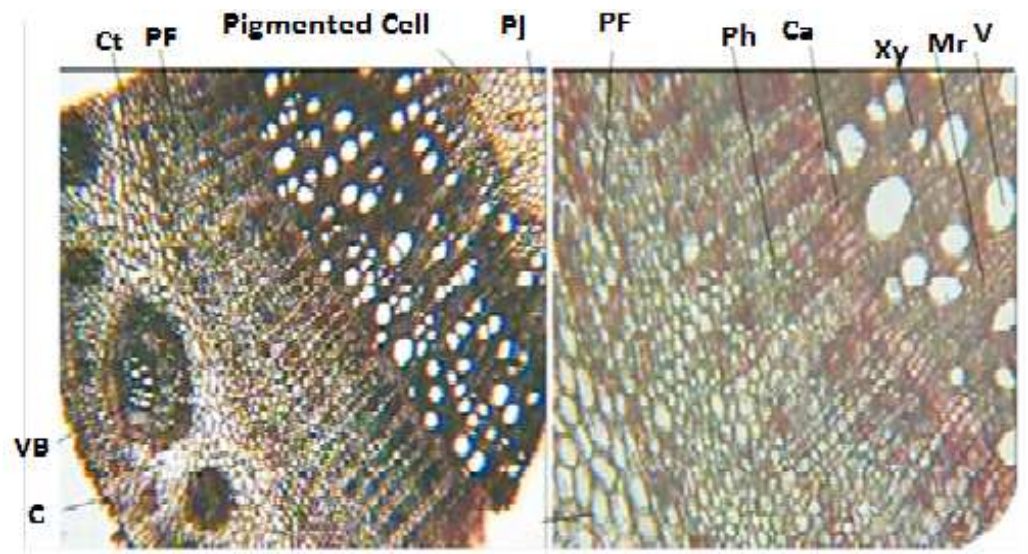

Fig. 3: T. S. of C. arborea stem. C: cork; Ct: cortex; VB: Vascular Bundle; Xy: Xylem; PF: Pericyclic Fibre; Ph: Phloem; Ca: Cambium; Mr: Medullary rays; V: Vessels; P: Pith

Stem bark microscopy $[9,10]$

Transverse section of bark has been reported to have prominent cork, cortex and secondary phloem. The cork cells consist of 8-16 layered, thick wall, rectangular and blackish brown in colour. Beneath the cork, there are 2-3 layers of phellogen and then the phelloderm. The cortex consists of rectangular to polygonal cells of parenchyma. The secondary phloem is made up of fibres, phloem parenchyma, medullary rays (1-2 seriate) and vessels. Calcium oxalate crystals are present in cells of cortex and phloem parenchyma in secondary phloem. Few starch grains are also found to be present.

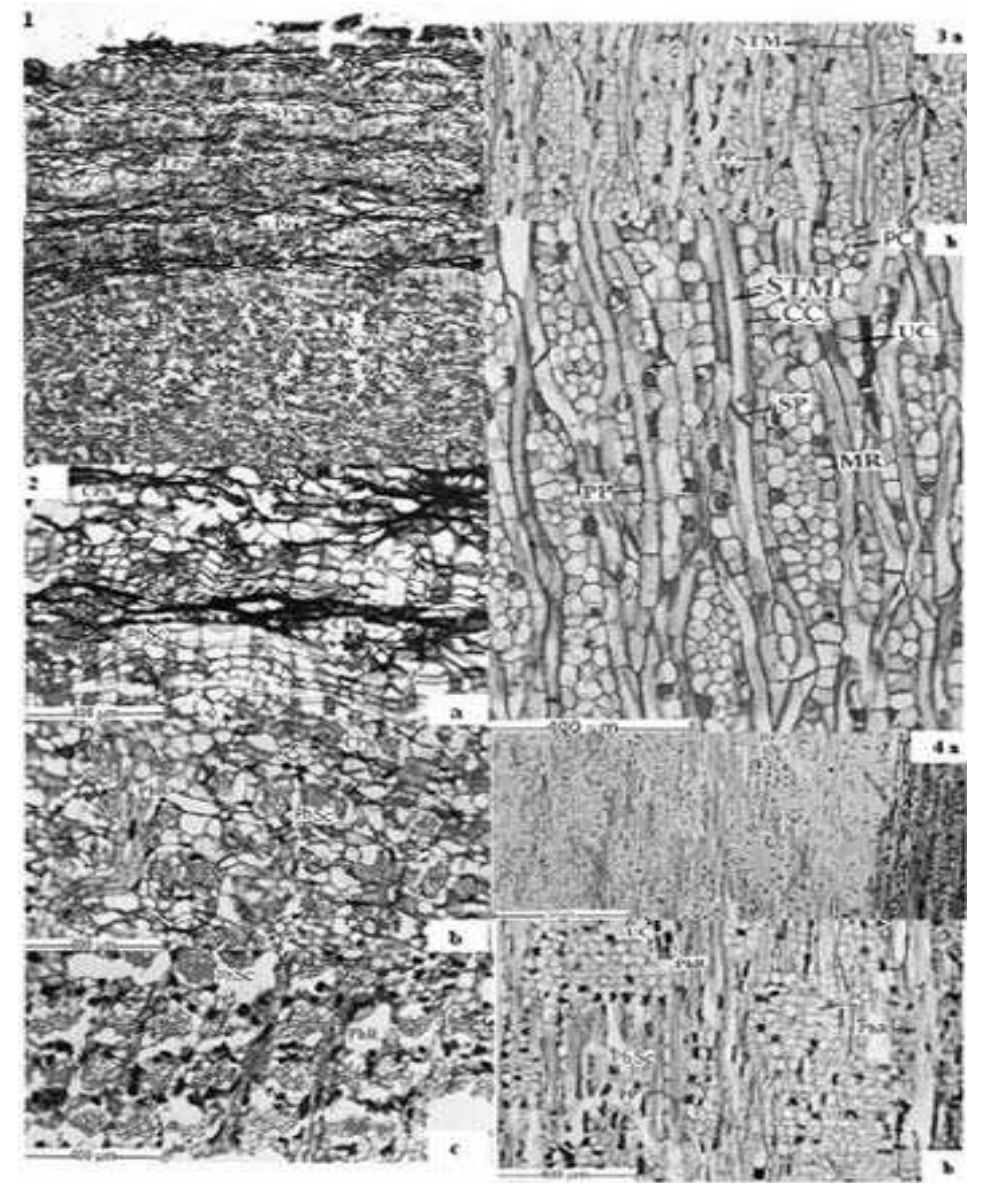

Fig. 4.1. T. S. of bark: (Cph-collapsed phloem; Fpe-First formed periderm; Lpe-Last formed periderm; Spe-Second formed periderm; TpeThird formed periderm), fig. 4. 2. The structure of three zones of bark: a) Outer rhytidome b) Middle collapsed phloem zone c) Inner noncollapsed phloem zone (Cph-Collapsed phloem; Pe-Periderm; PhR-Phloem ray; phsc-Phloem sclereids), fig. 4.3. TLS view of phloem: a) Non-storied multiseriate wide rays b) Sieve tube members and sieve plate structure of phloem rays (Cc-Campanion cells; MR-Multiseriate ray; PC-procumbent cells; PhR-phloem ray; PP-Phloem parenchyma; Sp-Sieve plate; STMSieve tube member; UC-Upright cells), fig. 4.4. RLS of phloem: a) Phloem rays as seen under low magnification b) Same as above under high magnification (Pc-Procumbent cells; PhRphloem ray; PP-Phloem parenchyma; Phsc-Phloem sclereids; UC-Upright cells) 


\section{Ethnopharmacological uses}

The therapeutical importance of Careyaarborea is mentioned in Materia Medica, Ayurveda, Siddha and Unani system of medicines. The root paste is used in body ache. Moreover, it is taken in the morning in empty stomach against joint pain for five days. Root-bark decoction (with long pepper) is used in fever, Stem-bark powder (paste with honey) is given to children in cold and cough; Stem-bark (paste with margosa) heals leucoderma. The bark of the tree and the sepals of the flowers are used as astringent and mucilaginous being administered internally in coughs and colds and applied externally as an embrocation. The stem bark of $C$. arborea is traditionally used in the treatment of tumours, bronchitis, skin disease, epileptic fits, astringent antidote to snake venom, abscesses, boil and ulcer [11]. Infusion of the flower is used after childbirth to heal rupture caused by childbirth.

\section{Physicochemical parameters}

Physicochemical parameters of the leaf and the stem bark are listed in table $1[8,12,13$,

Table 1: Physicochemical parameters of leaf and stem of $C$. arborea

\begin{tabular}{lll}
\hline Physicochemical constants & Leaf & Stem bark \\
\hline Foreign matter $(\% \mathrm{w} / \mathrm{w})$ & 0.20 \\
Total ash $(\% \mathrm{w} / \mathrm{w})$ & 6.00 \\
Acid insoluble ash (\% w/w) & 1.40 \\
Water soluble ash (\% w/w) & 2.20 \\
Loss on drying (\% w/w) & 3.20 \\
Swelling index (mL) & 4.70 \\
Water soluble extractive (\% w/w) & 18.4 \\
Alcohol soluble extractive (\% w/w) & 8.20 & 0.17 \\
\hline
\end{tabular}

Phytochemical screening, table 2 [14] revealed the presence of alkaloids, flavonoids, phenols, tannins, sterols and fixed oils.

Table 2: Phytochemical screening

\begin{tabular}{lll}
\hline Reagents & Color/precipitate & Constituents \\
\hline Mayer's reagent & No precipitate & Alkaloids absent \\
Dragendorff reagent & No precipitate & Alkaloids absent \\
$5 \%$ Ferric chloride test & Greenish black precipitate & Phenols present \\
N P reagent & Yellow fluorescence & Flavonoids present \\
$15 \%$ Ferric chloride test & Greenish black precipitate & Tannins present \\
Aq. Lead acetate & White precipitate & Tannins present \\
Lieberman Burchard's Test & Reddish brown colour & Sterols present \\
Spot test & Stains observed & Fixed oils present \\
\hline
\end{tabular}

\section{Phytochemistry}

The plant has been extensively investigated and chemical constituents from the barks, leaves and seeds of the plant have previously been reported to include triterpenoids [15], flavonoid [16], coumarin [17] saponins and tannins [18]. Careyaarborea also contains five Saponins (sapogenols-careyagenol A, B, C, D and E); sterols, $\alpha$-spinosterol and $\alpha$-spinosterone [7].

\section{Table 3: Phytoconstituents present in different parts of Careyaarborea}

\begin{tabular}{ll}
\hline Plant part & Phytoconstituents \\
\hline ROOTS & Phyto-estrogens, Sito-sterol [19] \\
STEM BARK & lupeol, $\beta$-sitosterol, betulin, betulinic acid, 1-[5-(1,3-benzodioxol-5-yl)-1-oxo-2,4 pentadienyl] piperidine[20] \\
SEEDS & $\alpha$-spinasterol, $\Delta 22$-stigmastenol [21]Triterpenoids: Barringtogenol C \\
LEAVES & Careyagenolide, maslinic acid, $\alpha$ hydroxyursolic acid [21]n-hexacosanol, $\alpha$-spinasterol, taraxerol, taraxeryl acetate, $\beta$ - \\
& sitosterol, ellagicacid and quercitin[16], Triterpene ester-careaborin[22], Tannins [23] valoneicacid dilactone[17] \\
FLOWERS & Steroids and triterpenoids, Phenols,Tannins [10] \\
\hline
\end{tabular}

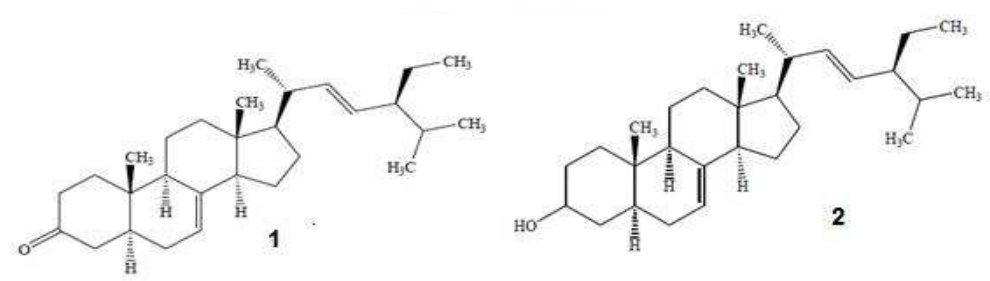

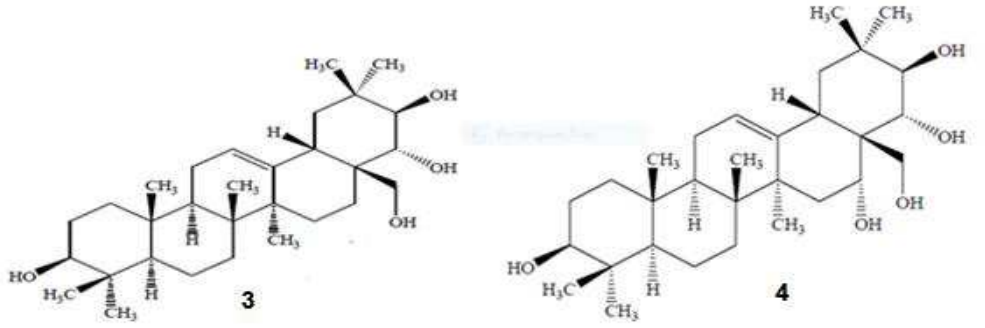



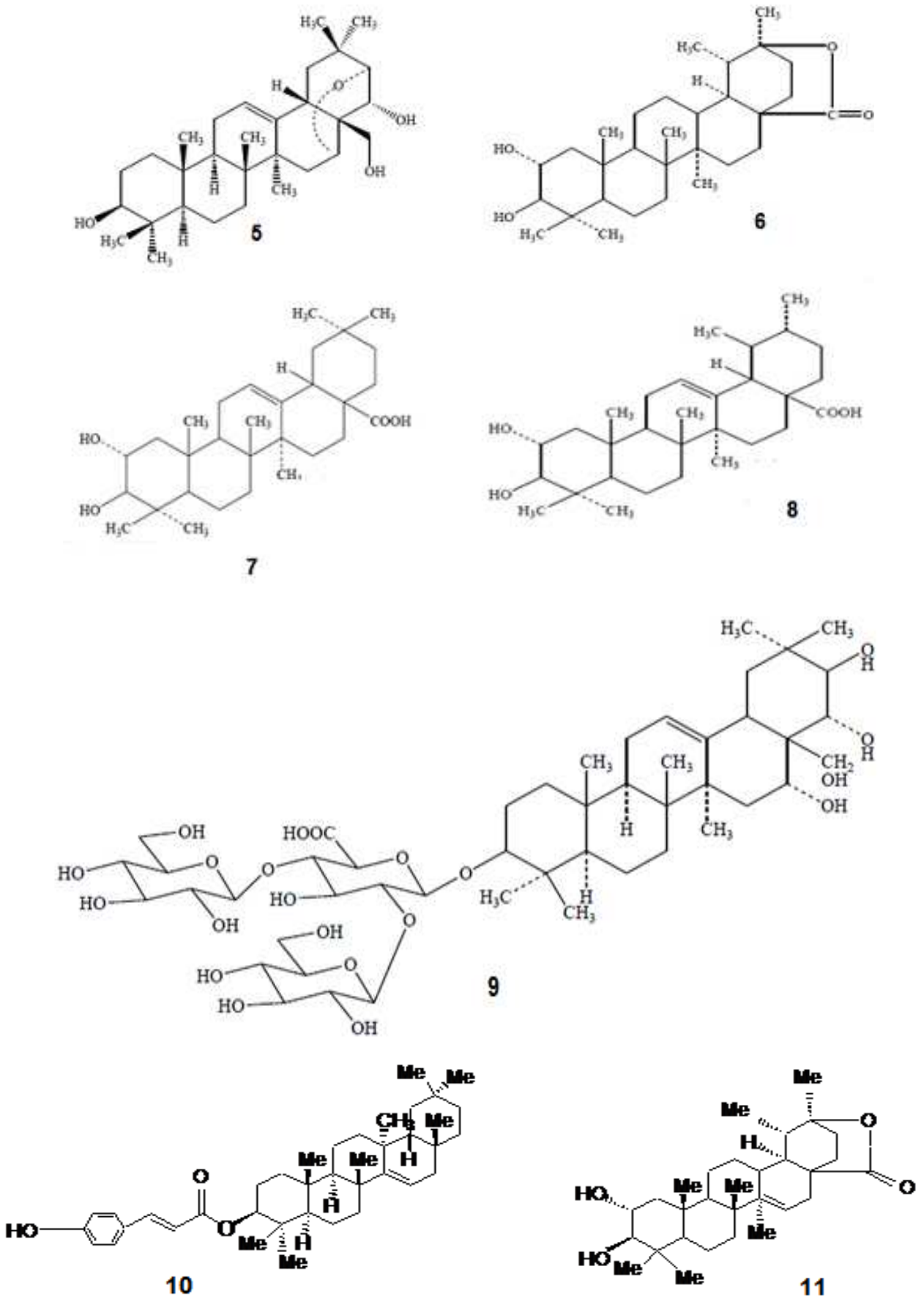<smiles>CC1CCC2C(=C3C=CC4C(C)(C)C(O)C(O)C4(CO)CCC32)CC1(C)C</smiles>

12

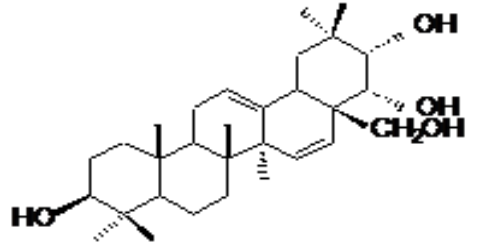

13

Fig. 5: Structures of some phytoconstituents present in Careyaarborea, 1. $\alpha$-spinasterone [21], 2. $\alpha$-spinasterol [21], 3. 16desoxybarringtogenol C [24], 4. Barringtogenol C [25-27], 5. Barringtogenol D [25-27], 6. Triterpenoid lactone careyagenolide [15], 7. Maslinic acid [15] and, 8. 2 $\alpha$-hydroxyursolic acid [15], 9. Desacylescin III [28], 10. Careyaborin-I [20], 11. Careyagolide [20], 12. Careyagenol E [20], 13. Careyagenol D [20] 


\section{Pharmacological profile}

\section{Hepatoprotective and antioxidant activity}

Sambhatkumar et al., (2005) [29] evaluated the hepatoprotective and antioxidant effect of methanolic extract of stem bark Careyaarborea Robx in Wistar albino rats. The hepatotoxicity was induced by carbon tetrachloride (30\% CCL4, $1 \mathrm{ml} / \mathrm{Kg}$ body weight in liquid paraffin. Three doses 50,100 and $200 \mathrm{mg} / \mathrm{kg}$ (i. p.) at $72 \mathrm{~h}$ interval and Silymarin $25 \mathrm{mg} / \mathrm{kg}$ were administered to the CCL4 treated rats. Analytical parameters like GOT, GPT, ALP, bilirubin, uric acid, and total protein were measured in the rat's induced hepatotoxicity by CCL4. The effect of the extract on Lipid Peroxidation, enzymatic antioxidant's and Catalase, and nonenzymatic anti oxidents, vitamin.

$\mathrm{C}$ and vitamin $\mathrm{E}$ were estimated. The extract and silymarin produced significant $(p<0.05)$ hepatoprotective effect by decreasing the activity of serum enzymes bilirubin, uric acid and lipid peroxidation and significantly $(\mathrm{p}<0.05)$ increased the level of SOD, CAT, GSH, vitamin C, vitamin $\mathrm{E}$ and protein in a dose-dependent manner. Thus, methanolic extract of stem bark Careyaarborea Robx possesses potent hepatoprotective and antioxidant activity. Senthil kumar et al., (2008) [30] studied the Antioxidant and hepatoprotective activity of the methanol extract of Careyaarborea bark in Ehrlich ascites carcinoma (EAC) bearing mice. Tumor control animals inoculated with EAC showed a significant alteration in the levels of antioxidant and hepatoprotective parameters. The extract treatment at 50, 100 and $200 \mathrm{mg} / \mathrm{kg}$ body weight doses given orally caused a significant reversal of these biochemical changes towards the normal in serum, liver and kidney when compared to tumor control animals indicating the potent antioxidant and hepatoprotective nature of the standardized extract.

\section{Anticancer activity}

Anticancer potentials of the methanol extract of Careyaarborea Roxb bark against Dalton's lymphoma ascites (DLA)-induced ascitic and solid tumors was studied by Natesan et al., (2007) [31]. The methanol extract of its bark given orally to mice at the dose of 250 or $500 \mathrm{mg} / \mathrm{kg}$ body weight for $10 \mathrm{~d}$ caused a significant reduction in percent increase in body weight, packed cell volume, and viable tumor cell count when compared to the mice of the DLA control group. Restoration of haematological and biochemical parameters towards normal was also observed. Histological observations of liver and kidney also indicated repair of tissue damage caused by tumor inoculation. The extract at the dose of 5 or $25 \mathrm{mg} / \mathrm{kg}$ body weight given i. p. daily for $14 \mathrm{~d}$ significantly reduced the solid tumor volume induced by DLA cells. Kumar et al., (2008) [32] studied the antimicrobial and antioxidant activities of methanol extract of Careyaarborea stem barks in various in vitro systems. Antimicrobial activities were carried out using disc diffusion methods with Gram positive and Gram negative strains of bacteria and some fungal species. The extract showed broad spectrum antimicrobial activity against all tested microorganisms. Antioxidant and free radical scavenging activities of methanol extract of Careyaarborea stem barks was assessed by using DPPH, superoxide anion radical, nitric oxide radical and hydroxyl radical scavenging assays. The result indicates that the methanol extract of Careyaarborea can use as antimicrobial and antioxidant agents.

\section{Antifungal activity}

Kumar R. S, 2006 [33] revealed the Antifungal activity of methanolic extract of the bark against Candida albicans, Aspergillus flavus, Aspergillus niger and Alternariasolani was revealed.

\section{CNS depressant activity}

Kumar et al., (2008) [32] studied the methanol extract of barks of Careyaarborea to investigate central nervous system activity in Swiss albino mice and Wistar albino rats. General behaviour, exploratory behaviour, muscle relaxant activity and phenobarbitone sodium-induced sleeping time were studied. The results revealed that the methanol extract of barks of Careyaarborea at 100 and 200 $\mathrm{mg} / \mathrm{kg}$ caused a significant reduction in the spontaneous activity (general behavioral profile), remarkable decrease in exploratory behavioral pattern (Y-maze and head dip test), a reduction in muscle relaxant activity, and also significantly potentiated phenobarbitone sodium-induced sleeping time, the result showed significant CNS depressant activity in tested animal models.

\section{Anti-ulcer activity}

Kamal Kumar, et al. 2013, [34] studied that ethanol extract of the stem bark of Careyaarborea Roxb. have anti-ulcer effect by using Models such as ethanol-induced, cold stress induced and pyloric ligation Model. The studies were performed on Wister rats of either sex. The anti-ulcer effect was contrasted with standard drug (ranitidine $30 \mathrm{mg} / \mathrm{kg}$ ) orally. The maxi mumulcer protection of ethanol extract of Careyaarborea has been shown in the Ethanolinduced and cold stress induced models and a significant effect was found at both $300 \mathrm{mg} / \mathrm{kg}$ and $600 \mathrm{mg} / \mathrm{kg}$ dose levels.

\section{Anti-diarrhoeal activity}

The methanol extract of the Careyaarborea Roxb. bark significantly reduced castor oil induced diarrhoea in mice. This effect supports the local traditional use of the plant against diarrhea and was proved by Rahman et al., (2002) [35].

\section{Anti-inflammatory and analgesic activity}

The anti-inflammatory and analgesic effect of methanolic extract of Careyaarborea stem bark is carried out by Sambathkumar et al., (2005) [29]. The effect on the acute and chronic phases of inflammation was studied in carrageenan, dextran and mediators (histamine and serotonin) induced paw edema and cotton pallet induced granuloma respectively. Analgesic effect was evaluated in acetic acid induced writhing and hot plate test.

The antiedema effect was compared with indomethacin $10 \mathrm{mg} / \mathrm{kg}$ orally. In the acute phase of inflammation a maximum inhibition of $50.56,48.86,47.12$ and $48.23 \%(p<0.05)$ was noted at the dose rate of $200 \mathrm{mg} / \mathrm{kg}$ b.w. after $3 \mathrm{~h}$ of treatment with methanolic extract in carrageen, dextran, histamine and serotonine induced paw edema respectively. Administration of methanolic extract at the dose of 200 $\mathrm{mg} / \mathrm{kg}$ and indomethacine $(10 \mathrm{mg} / \mathrm{kg})$ significantly $(\mathrm{p}<0.05)$ decreased the formation of granuloma tissue induced by cotton pellet method at a rate of $53.91 \%$ and $57.60 \%$ respectively. The methanolic extract revealed significant $(\mathrm{p}<0.01)$ analgesic activity in both models.

\section{Antifertility activity}

The methanolic root extract of Careyaarborea Roxb. Showed antifertility activity (pregnancy inhibition) in 3 mo old Swiss albino mice at the dose level $1000 \mathrm{mg} / \mathrm{kg}$ bw, when administered orally for a short period (14 d) by Jogen Chandra K et al., (2011) [36]. Animals were treated with different doses of extract: $250 \mathrm{mg} / \mathrm{kg} \mathrm{bw}, 500$ $\mathrm{mg} / \mathrm{kg}$ bw $750 \mathrm{mg} / \mathrm{kg}$ body weight and $1000 \mathrm{mg} / \mathrm{kg}$ body weight for a short period of 14 consecutive days. The extracts were administered orally at the $24 \mathrm{~h}$ interval. The minimum effective dose of the root extract to prevent pregnancy was found to be $500 \mathrm{mg} / \mathrm{kg}$. The dose of the extract that could induce strong pregnancy inhibitory activity was $1000 \mathrm{mg} / \mathrm{kg}$ bw. The root extract had a significant dose-dependent pregnancy inhibitory effect.

\section{Anticoagulant activity}

It was reported that the methanolic extract Careyaarborea (bark) possess anticoagulant activity via assay of activated partial thromboplastin time (aPTT), Prothrombin time (PT), and thrombin time (TT). It was shown that bark extract caused a significant increase $(p<0.05)$ in aPTT, PT and TT at all doses and results were almost equivalent to the response of warfarin [37].

\section{Market formulations}

\# Kumbhajatu Ayurveda Rasashala, treat hyperlipidemia [38].

\# Jigrine Hamdard Laboratories, treat liver problems [34, 40].

\# Habb-E-Kabid Naushadri Hamdard Laboratories treat liver disorders [41].

\# Hamdard Ghutti Hamdard Laboratories, a paediatric preparation used to treat constipation of newborn and infants [42]. 
\# Obenyl Tablet Charak Pharmaceuticals, to treat obesity [43].

\section{CONCLUSION}

This review concludes that Careyaarboreahas emerged as a good source of the traditional medicine for tumours, bronchitis, skin disease, epileptic fits, astringent antidote to snake venom and ulcers. Many traditional uses have now been evaluated by modern pharmacology research. Intensive investigations related to bioactive constituents for specific pharmacological action, their mechanism of action, safety and efficacy could be the future research interests to explore the plant exhaustively.

\section{CONFLICT OF INTERESTS}

Declare none

\section{REFERENCES}

1. Roxburgh, William. Plants of the Coast of Coromandel 3:13 and Tropicos, Careya Roxb; 1819.

2. Anderberg AA, Rydin C, Källersjö M. Phylogenetic relationships in the order ericales: analyses of molecular data from five genes from the plastid and mitochondrial genomes. Am J Botany 2002;89:677-87.

3. Mori SA, Tsou CH, Wu CC, Cronholm B, Anderberg AA. Evolution of Lecythidaceae with an emphasis on the circumscription of neotropical genera: Information from combined $\mathrm{ndhF}$ and trnL-F sequence data. Am J Botany 2007;94:289-301.

4. Anonymous: ayurvedic formulary of India, part 1. first ed. Govt. of India, NewDelhi; 1978. p. 6.

5. Yoganarsimha SN. Medicinal plant of India, Cyber media, Tamil Nadu, Banglore, II; 2000. p. 263.

6. Gurudeva MR, Divya CP. Botanical and Vernacular names of south Indian plants, Bangalore; 2001. p. 92.

7. The Ayurvedic Pharmacopoeia of India. Part-I. Vol. V; 2008. p. 1-199.

8. Gupta PC, Sharma N, Rao CV. Pharmacognostic studies of the leaves and stem of Careyaarborea Roxb. Asian Pac J Trop Biomed 2012;2:404-8.

9. Wadkar KA, Chandrakant MS. Pharmacognostic profiles of the bark of Careyaarborea Roxb. J Pharmacogn Phytother 2009;1:64-6.

10. Shanth TR, Pasupathy S, Yoganarasimhan SN. Identification, macro, microscopic and physicochemical details of a market sample of padmaka (CareyaarboreaRoxb). Indian J For 1987;10:131-9.

11. Nadkararni KM. Medicinal plants of India. Reprint Prakashan, Dehradun; 2004. p. 87.

12. Goyal KK, Kumar BNS, Mruthunjaya K, Yoganarasimhan SN. Pharmacognostic studies of stem bark of CareyaarboreaRoxb. Int J Green Pharm 2011;5:6.

13. Soni P, Sharma H, Bisen S. Physicochemical properties of Careyaarborea and Aesculus assamica starches. Biosynthesis Nutr Biomed 1989;41:208-11.

14. Ragavendran P, Radha A, Mariya Paul, Suresh Kumar D. A pharmacognostical report on careyaarborearoxb. (Lecythidaceae) fruits. Hygeia J D Med 2015;7:139.

15. Das MC, Mahato SB. Triterpenoidsapogenols from the leaves of the Careyaarborea structure of careyagenolide. Phytochemistry 1982;21:2069-73.

16. Gupta RK, Chakraborty NK, Dutta TR. Crystalline constituents from Careyaarborea Roxb. Indian J Pharm 1975;376:161-2.

17. Basak A, Banerjee BL, Basu K. Chemical examination of the leaves of Careyaarborea. J Indian Chem Soc 1976;53:639-40.

18. Kulakkattolickal A. Piscicidal plants of Nepal, Preliminary toxicity screening using grass carp (CtenopharyngodonIdella) fingerlings. J Ethnopharmacol 1987;21:1-9.

19. Haloi K, Kalita E, Kalit JC. Effects of methanolic root extract of CareyaarboreaRoxb on ovarian histology of albino mice. NEBIO 2010;1:14-7.

20. Yoganarasimhan SN. Medicinal plants of India (Karnataka). Interline Publishing Pvt Ltd, Bangalore, I; 1996. p. 95.

21. Mahato SB, Dutta NL. Phytochemistry: sterols from CareyaarboreaRoxb. IJRAP 1972;11:2116-7.

22. Talapatra B, Basak BA, Talapatra SK. Terpenoids and related compounds Part XX. Careaborin, a new triterpene ester from the leaves of CareyaarboreaRoxb. J Indian Chem Soc 1981;58:814-5.
23. Gupta R. Tannin bearing plants of India from denuded wastelands. J Economic Taxonomic Botany 1981;2:139-55.

24. ChakrabortiS, Barua A. Triterpenoids-XVI: The constitution of barringtogenol D-A new triterpenoid sapogenin from Barringtoniaacutangulagaertn. Tetrahedron 1963;19:1727-32.

25. Nakano T, Hasegawa M, Fukumaru T, Durham LJ, Budzikiewicz H, Djerassi C. Structure of jegosapogenol (barringtogenol. C, aescinidin) and the configuration at C-21and $\mathrm{C}-22$ in barringtogenol $\mathrm{D}$, aescigenin, protoaescigenin, and isoaescigenin. J Org Chem 1969;34:3135-46.

26. Yosioka I, Imai K, Kitagawa I. On genuine sapogenins of horse chestnut saponins by means of soil bacterial hydrolysis and a new minor sapogenin: Desoxybarringtogenol C. Tetrahedron Lett 1967;8:2577-80.

27. Mandal D, Panda N, Kumar S, Banerjee S, Mandal N, Sahu NP. A Triterpenoid saponin possessing antileishmanial activity from the leaves of Careyaarborea, Phytochemistry 2006;67:183-90.

28. Mahato S, Banerjee S, Chakravarti R. Taraxerol from Careyaarborea. Bull Calcutta School Trop Med 1967;15:8.

29. Sambath Kumar R, Sivakumar T, Sivakumar P, Nethaji R, Vijayabaskar M, Perumal P, et al. Hepatoprotective and in vivo antioxidant effects of Careya arborea against carbon tetrachlorideinduced liver damage in rats. Int J Mol Med Adv Sci 2005;1:418-24.

30. Senthilkumar N, Badami S, Cherian MM, Hariharapura RC. Potent in vitro cytotoxic and antioxidant activity of Careyaarborea bark extracts. Phytother Res 2007;21:492-5.

31. Natesan S, Badami S, Dongre SH, Godavarthi A. Antitumor activity and antioxidant status of the methanol extract of Careyaarborea bark against Dalton's lymphoma ascites induced ascitic and solid tumor in mice. J Pharmacol Sci 2007;103:12-23.

32. Kumar SR, Sivakumar P, Nethaji R, Senthil V, Murthy NV. CNS activity of the methanol extracts of Careyaarboreain experimental animal model, Bangladesh. J Pharmacol 2008;3:36-43.

33. Kumar RS, Sivakumar T, Sundaram RS, Sivakumar P, Nethaji R, Gupta M. Antimicrobial and antioxidant activities of Careyaarborea Roxb. stem bark. Iranian J Pharmacol Ther 2006;5:35-41.

34. Kumar. Anti-ulcer activity of ethanol extract of the stem bark of Careyaarborea Roxb. Int Curr Pharm J 2013;2:78-82.

35. Rahman MT, Khan OF, Saha SA, Alimuzzaman M. Antidiarrhoeal activity of the bark extract of CareyaarboreaRoxb. Fitoterapia 2003;74:116-8.

36. Jogenchandra K, Ansarul H, Evarani K, Ronim SM, Mukhlesur R. Antifertility effects of the methanolic root extract of careyaarborearoxb in albino mice. The bios can 2011;6:701-6.

37. Karunakar N, Pillai K. Investigations of anti-inflammatory activity of jigrine. Indian J Physiol Pharmacol 1997;41:134-8.

38. Ghosh R, Kadam PP, Kadam VJ. Antioxidant and hypolipidemic activity of Kummbhajatu in hypercholesterolemic rats. Int J Ayurveda Res 2010;1:159-62.

39. Ahmad A, Pillai KK, Najmi AK, Ahmad SJ, Pal SN, Balani DK. Evaluation of the hepatoprotective potential of jigrine posttreatment against thioacetamide-induced hepatic damage. J Ethnopharmacol 2002;79:35-41.

40. Najmi AK, Pillai K, Pal S, Aqil M. Free radical scavenging and hepatoprotective activity of jigrine against galactosamine induced hepatopathy in rats. J Ethnopharmacol 2005;97:521-5.

41. Good Hakeem: a family herbal store. Available from: http://buyherbalgoodhakeemcom/habb-e-kabinaushadrihamdard. [Last accessed on 25 Nov 2016]

42. Jelliffe DB, Jelliffe E, Naylor A. Breastfeeding for child survival Pakistan. A report prepared by British consultants; 1988.

43. Ayurveda for all: One-stop-shop for complete Ayurveda. Available from:http://wwwayurvedaforallcom/indexphp?osCsid=mc4ba3id ojv9cclsaq47 mjhip4.PsWd; diamond204. [Last accessed on $25 \mathrm{Nov}$ 2016].

\section{How to cite this article}

- Manbir Kaur, Rakesh Yadav. Pharmacognostic, ethnopharmacological, phytochemical and pharmacological profile of wild guava I.E. Careya arborearoxb. Int J Curr Pharm Res 2017;9(3):1-7. 